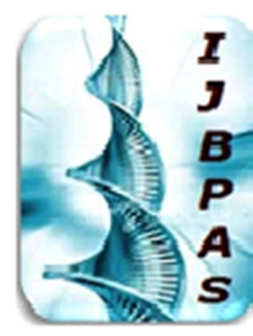

International Journal of Biology, Pharmacy and Allied Seiences (IJBPAS) 'A Bridge Betusen Caboratory and QRader'

WwW.ibpas.com

HISTORY AND RECENT PROGRESS IN CORONAVIRUS DISCOVERY

CH.VIJAYA LAKSHMI A*, KOUSHIK Y AND RAMA RAO N

Department of Pharmaceutical Regulatory Affairs, Chalapathi Institute of Pharmaceutical

Sciences Lam, Guntur, Andhra Pradesh, India-522034

*Corresponding Author: Ch. Vijaya Lakshmi: E-Mail: viijulucky2721997@gmail.com

Received 18 ${ }^{\text {th }}$ Jan. 2021; Revised 25 ${ }^{\text {th }}$ Feb. 2021; Accepted 24 ${ }^{\text {th }}$ March 2021; Available online $1^{\text {st }}$ Nov. 2021

https://doi.org/10.31032/IJBPAS/2021/10.11.5728

\begin{abstract}
Human coronaviruses, first identified in the 1960s, are responsible in children for a large proportion of upper respiratory tract infections. At least five new human coronaviruses, including the extreme acute respiratory syndrome coronavirus, have been reported since 2003 and have caused substantial morbidity and mortality. NL63, representing the newly identified group I coronavirus group, which includes NL and New Haven coronavirus, has been identified worldwide. These viruses are associated with both upper and lower respiratory tract diseases and are probably common human pathogens. The global distribution of the newly identified HKU1 group II coronavirus has not yet been established. Coronavirus Disease (COVID-19) now dominates the lives of all, and its history is constantly being rewritten. This article gives a brief account of the story so far: where SARS-CoV-2 may have originated, how it compares with other viruses that cause major respiratory diseases, and some of the treatments and vaccines currently being studied to combat it. Here, the background and history of this important and expanding research area are reviewed.
\end{abstract}

Key words: Coronavirus, NL63, HKU1, SARS-CoV-2, COVID-19

\title{
INTRODUCTION
}

\section{HISTORY OF CORONAVIRUS}

The history of coronaviruses reflects the discovery of coronavirus diseases and the identification of viruses. It begins with the first report of a new type of upper respiratory tract disease among chickens in North Dakota, USA, in 1931. In 1933, the causative agent was identified as a virus. By 1936, the disease and the virus had been recognized as unique to other viral 
diseases. A new brain disease of mice (murine encephalomyelitis) was discovered at Harvard Medical School in Boston in 1947. The virus that caused the disease was called JHM (after Harvard pathologist John Howard Mueller). Three years later, new mouse hepatitis was reported by the National Institute for Medical Research in London. The causative virus was identified as the hepatitis virus in the mouse (MHV) [3].

In 1961, a virus was obtained from a school boy in Epsom, England, who had a common cold. In 1965, the sample designated B814 was confirmed as a novel virus. New common cold viruses (assigned 229E) collected from medical students at the University of Chicago have also been reported in 1966. Structural analyzes of IBV, MHV, B18 and 229E using electron microscopy revealed that they all belong to the same group of viruses. Making a crucial comparison in 1967, June Almeida and David Tyrrell invented the collective name coronavirus, as all these viruses had solar corona-like projections (called spikes) on their surfaces.

Other coronaviruses have been discovered in pigs, dogs, cats, rodents, cows, horses, camels, Beluga whales, birds and bats. As of 2020, there are 39 species described. Bats are found to be the richest source of the different coronavirus species. All coronaviruses originated in a common ancestor some 293 million years ago.

\section{DISCOVERY OF HUMAN CORONAVIRUS:}

Human coronaviruses have been identified as one of the many common cold-inducing viruses. The study of common cold originated from the establishment of the Common Cold Research Unit (CCR U) in Salisbury in 1946 by the British Medical Research Council and the Ministry of Health. The research laboratory directed by Andrewes discovered many viruses that cause common cold, such as influenza viruses, parainfluenza viruses and rhinoviruses. In 1957, David Arthur John Tyrrell joined the CCRU and in 1962 he succeeded Andrewes. In 1960, for the first time, he developed a technique to grow rhinoviruses using nasal epithelial cells. Soon after, his team developed a notion of broad categorization of common cold viruses into two groups: one group, known as the $\mathrm{H}$ strain, could be maintained only in the culture of human embryo kidney cells, and another group, known as the M strain, could be maintained both in the culture of human embryo kidney cells and in the culture of monkey embryo kidney cells [3]. Tyrrell's team obtained throat swabs from 170 school boys with a common cold at a boarding school in Epsom, Surrey, between 1960 and 1961. England. Britain. A specimen designated B814, collected on 17 
February 1961, and was particularly infectious among healthy volunteers, among a few samples that could not be cultivated in any of the culture media. There was no evidence that the pathogen in B814 was a bacterium or a virus, as negative results were shown by all available bacterial and viral culture methods. Only in human tracheal culture could it be preserved and experimentally passed on by nasal inoculation to healthy volunteers.

In 1965 , they were able to confirm that the pathogen was a filter-passing virus susceptible to ether treatment (indicating a virus lipid envelope), capable of causing cold in volunteers treated with antibiotics (indicating that it was not a bacterium), and cultivated in the epithelial cell culture of human-embryo-trachea. Serological tests (antigen-antibody reactions) also showed that at that time the virus was not (not reactive) to any recognized virus antibodies (serotypes). Tyrrell and Malcolm L. Bynoe wrote their conclusion in the British Medical Journal, reporting as:

After considerable initial doubts, we now conclude that the B814 strain is a virus virtually unrelated to any other known human respiratory tract virus, even though it could be a myxovirus because it is etherlabile. But they contradicted themselves on the identity of the virus, as they pointed out in the experimental results, saying: It was concluded that B814 did not belong to any of the myxovirus serotypes used, but could be distantly related to influenza $\mathrm{C}$ or Sendai viruses.

In independent research in the United States, Dorothy Hamre and John J. Procknow studied respiratory tract infection among medical students at the University of Chicago. In 1962, five samples were collected which were associated with very different symptoms, causing mild cold only, and could only be grown in secondary human kidney tissue compared to other cold viruses which could be maintained in the embryo-kidney cell culture of the monkey [3].

The word 'coronavirus' was coined in 1968 , based on how its crown-like surface resembled the outer layer of the Sun, called the corona, under an electron microscope. Although the discovery of new coronaviruses such as 229E and OC43 created great media attention at the time one article boldly declared that 'science has tripled the chance of eventually licking the common cold' Dr. McIntosh remembers that after the advent of SARS in 2003, the scientific community did not consciously concentrate on studying coronaviruses again. Because 229E and OC43 induced relatively mild diseases in individuals, doctors could treat them much like other virus-induced colds: fever reducers, cough suppressants, and the occasional chicken 
soup bowl [4]. Then came the SARS outbreak of 2003, which originated in China with a coronavirus and eventually spread to 29 nations. While this disease was eventually reported to have affected only 8,096 individuals, a remarkably high mortality rate was attributed to 774 deaths, which led researchers to take a second look at the class of viruses.

"The world of coronaviruses suddenly changed when SARS came along and it became much larger and much more technical," recalls Dr. McIntosh. Since then, two other NL63 and HKU1 coldcausing coronaviruses have been discovered. And it wasn't until almost 50 years after its discovery in 2012 that the complete 229E genome was fully sequenced. In the meantime, a number of case reports have been reported showing that in patients with weakened immune symptoms, 229E could potentially cause serious respiratory symptoms, although its effect is mainly limited to a cold for most healthy people. Given the intensive examination that coronaviruses have undergone since SARS, it is still not entirely clear why three coronaviruses have led to much more serious symptoms and a higher mortality rate, SARS-CoV-1, MERS-CoV and SARS-CoV-2 (the cause of the COVID-19 pandemic), while the other four identified human coronaviruses remain much milder [4].

The World Health Organization (WHO) was officially informed on 31 December 2019 of a cluster of pneumonia cases in Wuhan City, home to 11 million people and central China's cultural and economic center. By 5 January, 59 cases were known and none were fatal. Ten days later, 282 cases were reported by the WHO, of which four were in Japan, South Korea and Thailand. In Wuhan, there were six deaths, 51 people were critically ill, and 12 people were in critical condition. The responsible virus was isolated on 7 January and shared its genome on 12 January. A novel coronavirus, SARS-CoV-2, was the cause of the extreme acute respiratory syndrome that became known as COVID-19. The rest is history, but history is continuously being rewritten: as of 12 May, 82,591 new COVID-19 cases were condemned worldwide on a regular basis and the death rate was over 4200 per day [5]. The Table 1 shows that maleficent 7 will say the coronavirus that affect humans.

The Maleficent 7:

Table: 1 Coronaviruses that affect humans: [5] [6]

\begin{tabular}{|c|c|c|c|}
\hline Virus strains & Years & Discovered & Causes \\
\hline 229E & 1965 & By university of Chicago & Cause of common cold \\
\hline OC43and B814 & 1967 & By NIH researchers & $\begin{array}{c}\text { Causes colds and likely passed to } \\
\text { humans from cattle in 18 } \\
\text { century } \\
\text { and } 1^{\text {th }}\end{array}$ \\
\hline HKU1 & 2005 & In Hong Kong & Causes respiratory tract infections and \\
\hline
\end{tabular}




\begin{tabular}{|c|c|c|c|}
\hline NL63 & 2004 & In Netherlands & $\begin{array}{c}\text { shows similarities to a coronavirus that } \\
\text { infects mice }\end{array}$ \\
\hline SARS-CoV-1 & 2003 & $\begin{array}{c}\text { Outbreak of SARS identified by } \\
\text { Canada's national microbiological } \\
\text { laboratory }\end{array}$ & $\begin{array}{c}\text { Causes mild or moderate upper } \\
\text { respiratory infections and more severe } \\
\text { infections of lower respiratory tract. }\end{array}$ \\
\hline MERS-CoV & 2012 & $\begin{array}{c}\text { More severe symptoms and a higher } \\
\text { mortality rate other four known human } \\
\text { coronaviruses remain much milder. }\end{array}$ \\
\hline SARS-CoV-2 & 2019 & $\begin{array}{c}\text { Center in Saudi Arabia } \\
\text { Identified in Wuhan, China }\end{array}$ & $\begin{array}{c}\text { More severe symptoms and a higher } \\
\text { mortality rate other four known human } \\
\text { coronaviruses remain much milder. }\end{array}$ \\
\hline & & $\begin{array}{c}\text { More severe symptoms and a higher } \\
\text { mortality rate other four known human } \\
\text { coronaviruses remain much milder. }\end{array}$ \\
\hline
\end{tabular}

\section{DISCOVERY OF STRUCTURE}

Normally, viruses cannot be seen using light microscopes. It was only with electron microscopy creation that viruses could be visualized and structurally elucidated. The coronavirus structure was first identified using transmission electron microscopy by Reginald L. Reagan, Jean E. Hauser, Mary G. Lillie, and Arthur H. Craige Jr. of the University of Maryland. In 1948, they reported in The Cornell Veterinarian that IBV was spherical in shape and some of them had filamentous projections. But the images were difficult to interpret due to poor resolution and low magnification (at $\times$ 28,000). Their subsequent studies did not show any striking properties from other viruses. Charles Henry Domermuth and O.F. made an important development. In 1957, Edwards observed IBVs as "ring or doughnut-shaped structures" [3]. Its D.M. Berry at Glaxo Laboratories, Middlesex, United Kingdom, J.G. Cruickshank, H.P. Chu and R.J.H. Wells at the University of Cambridge published a more comprehensive and better electron microscopic picture in 1964. Four IBV strains, including the Beaudette strain, were compared with the influenza virus, with which they have the most similarity. In contrast to the influenza virus in which the projections were small and straight, all IBV strains had "pear-shaped projections" that were referred to as "spikes" and described as:

These "spikes" were often seen only in part of the surface and were less densely packed than those seen in influenza viruses. They varied considerably in terms of shape. Usually they appeared to be attached to the virus by a very narrow neck and thickened towards their distal ends, sometimes forming a bulbous mass of 90-110 ̊ in diameter.

All 'IBV-like' viruses, 229E and IBV themselves have the following characteristics:

(1) An over-all diameter of $160 \mathrm{~m} \mu$ with a variation of $\pm 440 \mathrm{~m} \mu$;

(2) Moderate pleomorphism with resulting elliptical, round or tear-drop 
shapes but no filamentous or 'tailed' shapes;

(3) Characteristic spikes $20 \mathrm{~m} \mu$ long, narrow at the base and $10 \mathrm{~m} \mu$ wide at the outer edge, typically club- or pearshaped, widely spaced and fairly evenly distributed around the circumference of the particle [3].



Figure: 1 Structure model of coronavirus

From where did the Coronavirus come?

Experts say that SARS-CoV-2 originated from bats. This is how coronaviruses for Middle East Respiratory Syndrome (MERS) and Severe Acute Respiratory Syndrome (SARS) started. SARS-CoV-2 jumped to humans at one of Wuhan's openair "wet markets," where customers buy fresh meat and fish, including animals killed on the spot. Some wet markets sell wild or forbidden species such as cobras, wild boars, and raccoon dogs. Crowded conditions may allow different animal viruses to swap genes. Sometimes the virus changes so much that it can begin to infect and spread among humans. Still, the
Wuhan market was not selling bats at the time of the outbreak. That's why early suspicion also fell on pangolins, also known as scaly anteaters, which are sold illegally in certain markets in China. Some coronaviruses which infect pangolins are similar to SARS-CoV-2. As SARS-CoV-2 spread both inside and outside China, it infected people who had no direct contact with animals. This means that the virus is transmitted from one human to another. It is now spreading in the U.S. and around the globe, meaning that people are unwittingly catching and passing the coronavirus. This growing worldwide transmission is now a pandemic [7]. 


\section{Treatment under assessment of COVID-}

19:

In 1965, scientists first identified a human coronavirus. It was causing a common cold. Later that decade, researchers found a group of similar human and animal viruses, named after their crown-like appearance. Seven coronaviruses may infect humans. (4)(8) The one that causes SARS emerged in southern China in 2002 and spread rapidly to 28 other countries. By July 2003, over 8,000 individuals had been contaminated, and 774 had died. In 2004, a minor outbreak only included four more cases. This coronavirus causes problems with fever, headache, and breathing, including cough and shortness of breath. MERS began in 2012 in Saudi Arabia. Nearly all of the nearly 2,500 cases have resulted in individuals living in or traveling to the Middle East. This coronavirus is less infectious, but more lethal, killing 858 individuals than its SARS cousin. It has the same breathing symptoms, but it may also cause failure of the kidneys.

Supportive treatment and oxygen supplementation by non-invasive or mechanical ventilation are used to control the complications of COVID-19. For secondary bacterial infections, patients who are critically ill may need vasopressor help and antibiotics.

The search for drugs and vaccines to treat or prevent COVID-19 has begun quickly, but with many studies carried out independently in a small number of people, there is a risk that the trials will lack statistical rigour. A non-blinded clinical trial (SOLIDARITY) was initiated by WHO to determine the quality of care of four candidate therapies (remdesivir, lopinavir/ritonavir,

lopinavir/ritonavir/interferon beta-1a, and chloroquine or hydroxychloroquine) in 18 countries around the world. In Belgium, France, Germany, Luxembourg, the Netherlands, Spain, Sweden and the UK, France is co-ordinating the Discovery trial to equate the same medicines with standard treatment in 3200 patients. This will be randomized, but not blinded, and will test findings in 15 days $[\mathbf{4}, 9]$.

Table 2: Drugs under investigation for the treatment of COVID-19

\begin{tabular}{|c|c|c|}
\hline Candidate & Possible mechanism(s) of action & Developments status \\
\hline $\begin{array}{c}\text { Chloroquine or } \\
\text { hydroxychloroquine }\end{array}$ & $\begin{array}{c}\text { Impairs virus release after cell entry } \\
\text { Impairs virus binding to cell receptor } \\
\text { Modulates immune response } \\
\text { Hydroxychloroquine is associated with fewer } \\
\text { adverse effects than chloroquine }\end{array}$ & $\begin{array}{c}\text { Given FDA Emergency Use } \\
\text { Authorisation in the USA, but the } \\
\text { MHRA states it should only be used } \\
\text { within a clinical trial. Being } \\
\text { investigated in the WHO } \\
\text { SOLIDARITY trial }\end{array}$ \\
\hline
\end{tabular}




\begin{tabular}{|c|c|c|}
\hline $\begin{array}{c}\text { Hydroxychloroquine }+ \\
\text { azithromycin }\end{array}$ & $\begin{array}{c}\text { Hydroxychloroquine as above } \\
\text { Azithromycin - possible antiviral activity } \\
\text { and prevention of secondary bacterial } \\
\text { infection }\end{array}$ & $\begin{array}{l}\text { One trial suggests reduction in viral } \\
\text { nasopharyngeal carriage at } 6 \text { days in } \\
20 \text { patients compared with } \\
\text { unmatched untreated cohort, with } \\
\text { azithromycin reinforcing the effect of } \\
\text { hydroxychloroquine }\end{array}$ \\
\hline Lopinavir/ritonavir & $\begin{array}{c}\text { Viral protease inhibitors } \\
\text { May inhibit SARS virus and reduce adverse } \\
\text { outcomes of infection }\end{array}$ & $\begin{array}{c}\text { Randomised trial }(\mathrm{n}=200) \text { suggested } \\
\text { no benefit.36 Trial now underway in } \\
\text { combination with steroids. Being } \\
\text { investigated in the who solidarity } \\
\text { trial. }\end{array}$ \\
\hline Interferon beta-1a & $\begin{array}{c}\text { May counter suppression of interferon beta } \\
\text { by SARS-CoV-2 }\end{array}$ & $\begin{array}{l}\text { Administered by inhalation; trial } \\
\text { underway to determine impact on } \\
\text { severity of complications }\end{array}$ \\
\hline Remdesivir & $\begin{array}{c}\text { Blocks viral RNA synthesis } \\
\text { Broad-spectrum activity against } \\
\text { coronaviruses }\end{array}$ & $\begin{array}{l}\text { Given Emergency Use Authorisation } \\
\text { in the USA; EMA rolling review } \\
\text { underway. Clinical trials now } \\
\text { reporting preliminary results; ACTT } \\
\text { trial indicates beneficial effect on } \\
\text { time to recovery. One of the drugs in } \\
\text { the WHO SOLIDARITY trial }\end{array}$ \\
\hline Tocilizumab & $\begin{array}{l}\text { Blocks interleukin-6 signalling, which may } \\
\text { counter cytokine release syndrome in severe } \\
\text { COVID-19 }\end{array}$ & $\begin{array}{l}\text { Trial supported by US FDA } \\
\text { underway (COVACTA) in patients } \\
\text { with severe COVID-19 pneumonia }\end{array}$ \\
\hline Favipiravir + interferon alpha & $\begin{array}{c}\text { Blocks viral RNA synthesis } \\
\text { Stimulates innate antiviral response }\end{array}$ & Trials underway in China \\
\hline $\begin{array}{c}\text { Favipiravir + baloxavir } \\
\text { marboxil }\end{array}$ & $\begin{array}{l}\text { Blocks viral RNA synthesis } \\
\text { Baloxavir licensed in USA for flu }\end{array}$ & \\
\hline Favipiravir vs umifenovir & $\begin{array}{c}\text { Blocks viral RNA synthesis } \\
\text { Blocks virus-cell fusion }\end{array}$ & $\begin{array}{l}\text { In an unreviewed randomised non- } \\
\text { blinded trial ( } \mathrm{n}=\mathbf{2 4 0}) \text {, clinical } \\
\text { recovery rates at } 7 \text { days were similar } \\
\text { for favipiravir and umifenovir. Trials } \\
\text { of favipiravir underway in India }\end{array}$ \\
\hline $\begin{array}{c}\text { Ribavirin + interferon alpha, } \\
\text { lopinavir/ritonavir + interferon } \\
\text { alpha, and ribavirin }+ \\
\text { lopinavir/ ritonavir }+ \\
\text { interferon alpha }\end{array}$ & $\begin{array}{l}\text { Ribavirin may reduce viral replication } \\
\text { Triple therapy recommended by National } \\
\text { Health Commission of the People's Republic } \\
\text { of China. Guidelines for diagnosis and } \\
\text { treatment of novel coronavirus pneumonia } \\
\text { (Trial Version 5) } 2020\end{array}$ & Trials underway in China \\
\hline
\end{tabular}

\section{CONCLUSION}

COVID-19 poses an immense global problem that has demanded levels of action on an unparalleled scale. In one sense, there is a new threat: SARS-CoV-2 has arisen as a novel virus that humans have not been 
immune to, spreads extremely rapidly, has a high mortality rate, and can overpower the capacity of health systems to handle the most critically ill. Similarities with other coronaviruses and recent epidemics mean that infection prevention programs are well-proven and that current technologies can be deployed to promote the production of new vaccines and treatments.

\section{ACKNOWLEDGEMENT}

I am very grateful to Chalapathi institute of pharmaceutical sciences, Lam, Guntur, for providing necessary support, guidance and facilities.

\section{REFERENCES}

[1] Kahn, Jeffrey S. MD, PhD*; McIntosh, Kenneth $\mathrm{MD}^{\dagger}$ The Paediatric Infectious Disease Journal: history and recent advances in coronavirus discovery November 2005 -

Volume 24 - Issue 11 - p S223-S227

[2] Alex Knapp Forbes Staff Science The Secret History Of The First Coronavirus In Forbes Available URL: https://www.forbes.com/sites/alexknapp/202 0/04/11/the-secret-history-of-the-firstcoronavirus-229e/?sh $=3542 \mathrm{c} 11371 \mathrm{~d} 6$

[3] History of Coronavirus.

Available

URL: https://en.wikipedia.org/wiki/History_of_co ronavirus

[4]Alex Knapp Forbes Staff Science The Secret History Of The First Coronavirus In Forbes Available URL: https://www.forbes.com/sites/alexknapp/202 0/04/11/the-secret-history-of-the-first-

coronavirus-229e/?sh=3542c11371d6

[5]Steve Chaplin COVID-19 : Wiley Clinical Healthcare hub A brief history and treatments in development First published: $21 \quad$ May 2020 https://doi.org/10.1002/psb.1843

[6]A brief History of Human Coronavirus in the Scientific Exploring life Inspiring Innovation Available URL: https://www.the-scientist.com/newsopinion/a-brief-history-of-humancoronaviruses- 67600

[7] Hansa D. Bhargava, MD WebMD Medical Reference: Coronavirus History: Origin and Evolution on April 15, 2020.

[8]Jeffrey S Kahn Research Gate history and Recent Advances in Corona Discovery Available

URL:https://www.researchgate.net/publicati on/7393374_History_and_Recent_Advance s_in_Coronavirus_Discovery

[9]Lindsay Broadbent Research Fellow, School of Medicine, Coronaviruses-a brief history April 15, 2020 AEST Available URL:

https://theconversation.com/coronavirusesa-brief-history-135506

[10] National Library of Medicine (NIH) PubMed.gov Advanced Available URL: https://pubmed.ncbi.nlm.nih.gov/1637805

$0 /$. 